25.04.13 року [Електронний ресурс]. - Режим доступу: http://osvita.ua/legislation/Dist_osv/2999/. 8. Солдатки В. И. Образовательная среда сегодня и завтра / В. И. Солдаткин. - М. : Рособразование, 2004. - 272 с. 9. Terasic Technologies. Altera DE0 User Manual 2011. - 53. www.altera.com.

УДК 37.015.31:57.081.1

Евген Силко

\title{
ЕКОЛОГІЯ КУЛЬТУРИ ЯК НАЦІОНАЛЬНО ОРІЕНТОВАНА ПЕРСПЕКТИВА КУЛЬТУРОВІДПОВІДНОГО ВИХОВАННЯ ПІДРОСТАЮЧОГО ПОКОЛІННЯ В УМОВАХ ГЛОБАЛІЗАЦЇ̈
}

Силко С. М. Екологія культури як національно орієнтована перспектива культуровідповідного виховання підростаючого покоління в умовах глобалізації.

Статтю присвячено актуальній проблемі збереження природи народу (етноприроди) в умовах всеохоплюючих глобалізаційних процесів. Культуровідповідне виховання позиціонується як один із найефективніших інструментів гуманізації й екологізації соціально-культурного середовища, надання йому духовного осмислення.

Ключові слова: культура, глобалізація, екологія, виховання, духовність.

Силко Е. Н. Экология культуры как национально ориентированная перспектива культуросообразного воспитания подрастающего поколения в условиях глобализации.

Статья посвящена актуальной проблеме охраны природы народа (этноприроды) в условиях всеобъемлющих глобализационных процессов. Культуросообразное воспитание позиционируется как один из наиболее эффективных инструментов гуманизации и экологизации социально-культурной среды, придание ей духовной осмысленности.

Ключевые слова: культура, глобализация, экология, воспитание, духовность.

Sylko E. M. Ecology of culture as a national oriented perspective of the cultural upbringing of the younger generation in the context of globalization.

The article is dedicated to the actual problem of nature of the people protection in ecology culture. Upbringing in accordance with the nature is positioned as one of the most effective tools of humanization and greening of the socio-cultural environment, giving it a spiritual meaning.

Key words: culture, globalization, ecology, education, spirituality.

Нині все більше уваги звертається на два основні чинники сучасного світового процесу, що здатні вплинути на розвиток культури загалом та освіти й виховання зокрема. 3 одного боку, це бурхливий розвиток науково-технічного прогресу та процесів глобалізації, а з іншого,- викликані ними соціальні й екологічні проблеми. Наука i техніка в сучасному суспільстві дистанціювалися від людини, а технократичне мислення починає втрачати те мірило, яке повинно характеризувати будь-яку форму людської діяльності, що має гуманістичну спрямованість. Іншими словами, ця дистанція нівелює духовність і моральність як домінанти людського існування.

Проблема взаємозв'язку людини 3 культурним середовищем відповідної спільності ставала предметом дослідження науковців найрізноманітніших галузей 
знань [1; 11]. На думку В. Зінченка, «людина може перебувати в культурі і залишатися поза нею, може бути таким самим порожнім місцем, як для неї культура, дивитися на неї незрячими очима, проходити крізь неї як крізь порожнечу, не «забруднитися» й не залишити на ній своїх слідів» [5, с. 35]. Як справедливо наголошує на основі глибокого системного аналізу безлічі підходів до культури А. Запесоцький, існує кілька сотень їі визначень [3, с. 149]. Аналіз їх змісту дозволив автору зафіксувати феноменологічну сутність культури: «... як сукупності цінностей, норм, ідеалів, характерних для соціальної спільності (етносу, нації, товариства), зафіксованих і закріплених у текстах, переказах, звичаях, традиціях і забезпечують сенс існування людини і суспільства» [3, с. 150-151].

В останні роки проблеми екології природи, людини, культури настільки актуалізувалися, вийшли на перший план, їм приділяється стільки уваги, що створюється враження, начебто і екологічна свідомість, і екологічна культура, i екологія культури - цілком сучасні явища [8; 7]. Однак екологічні критерії споконвіку враховувалися в людській діяльності з цією різницею, що сучасний вимір проблеми характеризується більш усвідомленим застосуванням, спеціальними розробками, заглибленням та інтеграцією - від біохімічної до соціокультурної.

На думку вітчизняних і зарубіжних дослідників (А. Зеленков, В. Крисаченко, М. Можейко, А. Мороз, В. Костицький), настає епоха екологізації (як щодо збереження навколишнього середовища, так i щодо збереження культурного середовища), яка буде домінантним ціннісним орієнтиром третього тисячоліття. До багатьох нині приходить розуміння того, що примітивні матеріальні потреби не можуть бути абсолютною цінністю в житті сучасної людини.

Нерозв'язаним нині залишається питання змістовного наповнення екології культури, iї завдань та екології взагалі як супутнього явища сучасної цивілізації. Екологію не можна наповнювати лише завданнями збереження природного біологічного середовища. Для життя людини $є$ не менш важливим середовище, створене культурою іiї пращурів та нею самою. Збереження культурного середовища завдання не менш суттєве, ніж збереження навколишньої природи. Якщо природа необхідна людині для іï біологічного життя, то культурне середовище $є$ настільки ж необхідним для іiї духовного, морального життя, для іiї «духовної осілості», для іiі прив’язаності до рідної місцевості, для ії моральної самодисципліни і соціальності.

Mema cmammi- розкрити значення екології культури в якості антиглобалізаційного чинника; окреслити коло інтересів екології культури, розкрити iii духовну основу; визначити спільний знаменник процесів екологізації: культурне середовище, природне середовище як ії̈ об'єкти.

Розвиток освіти як соціального інституту зумовлений багатьма чинниками та умовами функціонування суспільства. Однак найбільш тісним можна вважати взаємозв'язок освіти і культури. Основним для освітньої діяльності є саме принцип культуровідповідності, який означає навчання і виховання в контексті культури, орієнтацію освіти на культурні цінності, опанування та збереження кращих світових досягнень людства, прийняття соціокультурних норм суб'єктами навчальновиховного процесу, їх подальший розвиток [10, с. 14].

Проблема зближення націй і розширення культурних контактів народів, що наприкінці 80-х рр. XX століття отримала назву «глобалізація культури» [6], в умовах технологічно й інформаційно високорозвиненого суспільства невідворотно призводить до створення одноманітного, стандартного, знеособленого життєвого соціально-культурного середовища. Масова культура, особливо в умовах іiі сильної 
комерціалізації, здатна витісняти і високу, і народну культури. Цінності національної культури підмінюються зразками масової культури, що зорієнтована на так звану «вестернізацію» культурних потреб й інтересів, передовсім молодіжних груп населення [9]. У переліку різноманітних негативних наслідків цього явища реальною загрозою $\epsilon$ знецінення i фактичне знищення національної самобутності, або етнокультурної ідентичності сучасного світу, що оточує людину. Духовність починається 3 національної самоідентифікації, пізнання народної культури. Коли відбувається послаблення зв'язків особистості з певним середовищем або спільністю на тлі віртуального звуження світової цивілізації [4], закладається початок існування особистості поза образами традиційної духовної й художньої культури.

Для багатьох українців, передовсім молоді, характерною $є$ відсутність етнокультурної або національної самоідентифікації, вони перестають сприймати себе як українців, втрачають свою українськість. Соціалізація молоді проходить або на традиційно-радянській, або на західній моделі виховання, у будь-якому разі, позанаціональній. Українська народна культура (традиції, звичаї, обряди, фольклор) більшістю молодих людей сприймаються як анахронізм.

3 огляду на таку ситуацію, все частіше порушується проблема втрати органічної єдності сучасної людини (особистості) з власною етноприродою. Екологія культури якраз покликана відновити фактично втрачений зв'язок, використовуючи в своєму арсеналі одну 3 найбільш дивовижних якостей культури - в умовах будь-якого прогресу, за будь-якої віднесеності до загальнолюдських цінностей вона здатна розвиватися, зберігаючи свою національну самобутність.

Але варто говорити і про позитивні тенденції в розвитку культури як відповідь на виклики часу. Наступ глобалізованого світу на природні й культурні цінності, криза «інтернаціональної культури» зумовили зростання інтересу до формування аутентичного життєвого середовища як відображення культурних традицій, його етнокультурної своєрідності. Ми вбачаємо в цьому один із можливих шляхів гуманізації й екологізації соціально-культурного середовища, надання йому духовного осмислення. У сучасних умовах тотальної відкритості, доступності культур, легкості отримання інформації проблеми культурної ідентичності посіли одне 3 провідних місць у галузі екології культури. Особлива увага приділяється питанням, так чи інакше пов'язаним із проблемами національної своєрідності, 3 традиціями національної культури [2].

Екологія культури, на наше глибоке переконання, повинна передбачати й формування нової структури (або кардинальне оновлення наявної) потреб особистості, оскільки ядро еколого-культурної проблематики складає національноціннісні уявлення суспільства від найдавніших часів до сьогодення. Під екологічними розуміються будь-які культурні концепції, спрямовані, так чи інакше, на гармонізацію взаємозв'язків людини 3 культурою його народу, національними особливостями, етноприродою загалом. I вже крізь цю призму (призму національного світогляду та самосвідомості) - гармонізація взаємозв'язків з навколишнім світом.

Саме в національно-ціннісних установках найбільш яскраво виявляються концепції екології культури. Тобто завдання екології культури передбачають, з одного боку, удосконалення екологічної ситуації, що склалася, шляхом виокремлення й поширення національно орієнтованих установок (народна культура) у ставленні людини до довкілля, 3 іншого, - цілеспрямований розвиток самого суспільства, можливе стимулювання в ньому органічності, чуттєвості, емоційності й національної самосвідомості. 
Пріоритет духовних цінностей, як зазначалося вище, неможливий без сформованої системи морально-етичних норм. Від рівня моральної культури людини залежить екологічний стан нашої планети. Відомо, що в основі природоцентризму української народної культури лежить поняття геокультурної єдності, яке передбачає єдність природно-кліматичних, астрономічних, біологічних ознак конкретної території, які впливають не лише на характер, світогляд людини, а й на вид діяльності, соціально-культурні взаємозв'язки тощо. Кожен природний ландшафт накладає свій відбиток і на систему виховання і навчання підростаючого покоління. Складники «Людина», «Життя», «Природа», «Виховання», «Культура» створюють нерозривне природне коло, з якого неможливе вилучення якогось компоненту.

Отже, ми розглядаємо навколишню природу та етноприроду як єдиний синкретичний комплекс, в умовах якого розвивається людина, а процес екологізації як відновлення втрачених зв'язків із предметами та явищами навколишньої природи і складниками народної культури. Криза органічної єдності особистості людини з цими двома сферами створює однаково загрозливу ситуацію задля подальшого розвитку та існування суспільства взагалі. Маємо справу 3 прямим взаємозв'язком - занепад духовності провокує аморальне ставлення й до навколишнього природного середовища. Тому розв'язання цієї глобальної проблеми потребує комплексного підходу - формування екологічної свідомості на основі відродження національних традицій у ставленні до довкілля.

Стрижнем екології культури є світогляд (фокус людського бачення світу), що відображає загальнолюдські і специфічні для кожного конкретного суб'єкта цінності й тим характеризує системотворчу якість культури - духовність. Необхідно підкреслити, що саме поняття духовності розкриває потребу в пізнанні світу, свого культурного минулого й сьогодення, сенсу і призначення свого життя. Звідси випливає важливий висновок для екології культури щодо необхідності відродження гуманістичного світогляду як незмінної константи в розвитку цивілізації, критерію справжнього людського прогресу.

Виходячи $з$ цього, коло інтересів екології культури (як соціального чинника екології) визначається нами як: пізнання процесів і результатів взаємодії людини 3 культурним середовищем; відповідальність за етноприроду як національну цінність; проблема усвідомлення особистістю власної національної приналежності як один із можливих шляхів гуманізації й екологізації соціально-культурного середовища, надання йому духовного осмислення.

Однак нині, на нашу думку, має розв'язуватися питання не лише фізичного збереження традицій і звичаїв. Виступаючи на захист народної культури, варто шукати в ній джерело інновацій. Відомо, що наші пращури жили в органічній єдності 3 навколишньою природою, вміли шанувати іiі та оберігати. Накопичені багатовікові природоохоронні традиції повинні бути першоосновою на шляху формування сучасного коеволюційного світогляду (співрозвиток), оскільки дійсно народне завжди універсальне. Адаптація цих традицій до сучасних реалій розвитку суспільства перспектива подальших досліджень.

\section{Література}

1. Грушевицкая Т. Г. Основы межкультурной коммуникации : [учебник для вузов] / Т. Г. Грушевицкая, В. Д. Попков, А. П. Садохин. - М. : ЮНИТИ-ДАНА, 2002. - 352 с. 2. Дмитренко М. К. Українська фольклористика: акценти сьогодення / М. К. Дмитренко. - К. : Сталь, 2008. - 236 с. 3. Запесоцкий А. С. Образование : философия, культурология, политика / А. С. Запесоцкий. - М. : Наука, 2002. - 456 с. 
4. Згуровский М. Г. В водовороте глобализации: вызовы и возможности / М. Г. Згуровский // Зеркало недели. Украина. - № 45. - [Електронний ресурс]. Режим доступу до статті: http:/gazeta.zn.ua/ SCIENCE /v_vodovorote_globalizatsii_vyzovy_i_vozmozhnosti.html. 5. Зинченко В. П. Психологическая педагогика. Материалы к курсу лекций. Часть І. Живое знание / В. П. Зинченко. - Самара : Издательство СГПУ, 1998. - 216 с. б. Канаев Н. М. Глобализация и высшее образование. Взгляд из ЮНЕСКО / Н. М. Канаев // Философия образования. - 2005. - № 1 (12). - С. 26-31. 7. Кисельов М. М. Національне буття серед екологічних реалій / М. М. Кисельов, Ф. М. Канак. - К. : Тандем, 2000. - 273 с. 8. Кисельов М. М. Концептуальні виміри екологічної свідомості / М. М. Кисельов, В. Л. Деркач, А. В. Толстоухов. - К. : Вид. Парапан, 2003. - 312 с. 9. Кушнарьова Н. Б. Основні тенденції розвитку масової культури в сучасній Україні в контексті глобалізації. Українські культурні дослідження / Н. Б. Кушнарьова. - [Електронний ресурс]. - Режим доступу до статті: http://www.culturalstudies.in.ua/ zv_2005_s6.php. 10. Основи викладання мистецьких дисциплін: [навч. посіб.]. за заг. ред. О. П. Рудницької. - К. : АТЗС «Експрес-об’ява», 1998. - 114 с. 11. Шинкаренко О. В. Природа і культура. Історія світової культури / О. В. Шинкаренко. - К. : Либідь, 2003. - 253 с.

УДК $378.14+372$.

Крістіна Тамбовська

\section{ІНТЕЛЕКТУАЛЬНА КУЛЬТУРА Й ІНТЕЛЕКТУАЛЬНИЙ РОЗВИТОК ФАХІВЦЯ ЯК СТРАТЕГІЧНА МЕТА ЯКІСНОЇ ПЕДАГОГІЧНОЇ ОСВІТИ}

Тамбовська К. В. Інтелектуальна культура й інтелектуальний розвиток фахівця як стратегічна мета якісної педагогічної освіти.

У статті розглянуто проблему визначення інтелектуальної культури, яка розуміється нами як складне особистісне утворення і визначається з урахуванням етимології понять «інтелект» і «культура», ураховує специфіку професійно значущих рис особистості майбутнього вчителя початкової школи, передбачає реалізацію визначених функцій у системі професійної діяльності та сфері особистого життя.

Ключові слова: інтелект, культура, інтелектуальна культура, інтелектуальний розвиток фахівця, вчитель початкової школи.

Тамбовская К. В. Интеллектуальная культура и интеллектуальное развитие специалиста как стратегическая цель качественного педагогического образования.

В статье рассмотрино проблема определения интеллектуальной культуры, которая понимается нами как сложное личностное образование и определяется исходя из этимологии понятий «интеллект» и «культура», учитывает специфику профессионально значимых черт личности будущего учителя начальной школы, предусматривает реализацию определенных функций в системе профессиональной деятельности и сфере личной жизни.

Ключевые слова: интеллект, культура, интеллектуальная культура, интеллектуальное развитие специалиста, учитель начальной школы.

Tambovskaya K. V. Intellectual culture and intellectual development of specialist as a strategic aim of quality pedagogical education. 